\title{
Discrimination in the Labor Market: Exposing Employment Barriers among Muslim Jobseekers in Australia
}

Terence Lovat

Faculty of Education and Arts, University of Newcastle

Callaghan NSW 2308, Australia

E-mail: Terry.Lovat@ newcastle.edu.au

\section{Pam Nilan}

Faculty of Education and Arts, University of Newcastle Callaghan NSW 2308, Australia

E-mail: Pamela.Nilan@newcastle.edu.au

\section{S. A. Hamed Hosseini}

Faculty of Education and Arts, University of Newcastle Callaghan NSW 2308, Australia

E-mail: Hamed.Hosseini@ newcastle.edu.au

\section{Ibtihal Samarayi}

Faculty of Education and Arts, University of Newcastle Callaghan NSW 2308, Australia

E-mail: Ibtihal.Samarayi@ newcastle.edu.au

\section{Michelle Mansfield}

Faculty of Education and Arts, University of Newcastle

Callaghan NSW 2308, Australia

E-mail: Michelle.M.Mansfield@ newcastle.edu.au 


\author{
Wendy Alexander (Corresponding author) \\ Faculty of Education and Arts, University of Newcastle \\ Callaghan NSW 2308, Australia \\ E-mail: Wendy.Alexander@ newcastle.edu.au
}

Received: August 25, 2013 Accepted: September 30, 2013 Published: November 24, 2013

doi:10.5296/iss.v1i1.4374 URL: http://dx.doi.org/10.5296/iss.v1i1.4374

\begin{abstract}
This article reports the findings of a multi-method study to assess barriers to employment among Muslim jobseekers and the relative effectiveness of employment services designed to support them. In August 2010, the United Nations Committee on the Elimination of Racial Discrimination noted with concern reports from Australia that highlighted 'ongoing issues of discrimination and inequity ... experienced by members of certain minority communities including African communities, people of Asian, Middle Eastern and Muslim background' (United Nations, 2010: 3). For Muslims in Australia, a point of concern is seen in unusually high unemployment rates, especially given the relatively strong qualification rates to be found in the Australian Muslim population. Using survey and interview data, we describe and interpret this phenomenon using both the jobseeker and service provider perspectives. We found Muslim jobseekers struggle to deal with structural obstacles such as inadequacy of services, as well as subjective misunderstandings and discriminatory behaviours.
\end{abstract}

Keywords: employment, labor discrimination, religion, Muslim, Australia 


\section{Introduction}

This article reports key findings of a study funded by the Australian Government's Department of Immigration and Citizenship (DIAC): 'Australian Muslim Jobseekers: Labour Market Experience, Job Readiness, and the Relative Effectiveness of Employment Support Services' (DIAC, 2011). The aim of the study was to find out about barriers to employment faced by jobseekers of Muslim faith in Australia, including those who came into contact with Job Services Australia (JSA) which was established to assist people in finding work.

We were aware from the outset that studying 'Muslim Jobseekers' per se was unusual, granted that 'Muslim' connotes a religious rather than a broader social category. Moreover, extant research suggests that educational background, ethnicity, English-speaking competence, gender and age, are the major indicative categories for employment wellbeing, whereas religion is of marginal consideration at best. Indeed, the idea that religion would in any way influence employment status seems, on the surface, to denote a return to earlier sectarian eras in Australian history when religious prejudice in employment practices was notable. Not only does the Equal Employment Opportunity policy now outlaw such prejudice, but most Australians would likely see religious discrimination as an outdated and unacceptable practice, now eschewed in favour of fairer and more objective employment criteria related to skills, experience and adaptability.

Yet research indicates subtle forms of 'Islamophobia' that have developed in the West, especially in the era of the 'Post 9/11 War on Terror' (Byng, 2008; PEW, 2011) and Australia is no exception. Furthermore, new forms of racism have emerged under the categories of 'covert racism' or 'cultural racism' (Coates, 2011). So a category like 'Muslim', even though ostensibly protected against religious discrimination by relevant legislation, can nonetheless present in instances of stigmatization, stereotyping, and marginalization. So just as other forms of discrimination persist in covert ways, 'faithism' - prejudice against someone on the basis of religious faith - can also prevail.

Unfortunately, despite a long history (see below) of Muslim participation in Australia, in contemporary debates 'Muslim' connotes a late twentieth-early twenty-first century incursion population, at least for the popular imagination. This is particularly so amidst emotive discussions over recent refugee and immigrant arrivals in Australia from Muslim majority countries. Here, we find a troubled and troubling discourse about whether these newly-arrived Muslims can integrate into Anglo-majority Australia and cope with Western cultural traditions. This phenomenon effectively constitutes a form of faithism, constituting a 'moral panic' over the suitability of Islam as a constitutive part of contemporary Australia (Poynting \& Mason, 2007; Rashid, 2007).

Regardless of whether it happens or not, because of legislation prohibiting 'faithism', any link between religion and unemployment is usually indiscernible in Australian Bureau of Statistics (ABS) data. Therefore, at the time the study was commissioned, it was not possible for us to obtain clear statistics about Muslim jobseekers as such. Indeed, there was little evidence of the link even in international literature, although recent UK data (Khattab, 2012) reveals a pattern not dissimilar to that discerned in our Australian study. Lack of data when 
the study began meant that the category of Australian Muslim jobseekers was a 'hard-to-reach' population (see Adeleke \& Ibiwoye, 2011). Jobseekers of Muslim faith in Australia are a highly diverse group, with wide variations in ethnicity, educational attainment and labor market experience. They are first, second and third generation immigrants, including refugees. Many are highly educated, skilled workers, but some have little education or work experience. Some are native speakers of English while others have little to no English proficiency. In spite of these limitations, we were able to discern trends important to the tenor of the study, including the observation that Muslim jobseekers are commonly understood not as a religious category, but as a social, cultural and statistical category and one that is often subject to discrimination (Poynting \& Noble, 2004; Quayle \& Sonn, 2009; Sanitosis, 2004; Salleh-Hodden \& Pedersen, 2012).

\section{Literature Review}

Historically, the Muslim faith in continental Australia pre-dates the British colonial period, with the Buginese people of Makassar developing commercial, social and enduring spiritual relationships with the Indigenous people of Northern Australia as early as the sixteenth century (Lloyd et al., 2010). In the late nineteenth century, Muslim cameleers facilitated British occupation and development of the arid interior. Islamic communities built mosques, ranging from makeshift tin structures to permanent buildings like the 1888 Adelaide Mosque which still stands today.

The Muslim population grew from 22,300 in 1971 to 476,300 (2.25\% of the total population) in 2011 (ABS, 2012), with the majority concentrated in Sydney and Melbourne. In 2006, $38 \%$ of the Muslim population was Australian-born (DIAC, 2006). In the 1970s and 1980s, Muslim migrants were primarily Turkish and Lebanese working in manufacturing and construction (Wise \& Ali, 2008). Arrivals increased under humanitarian programs, with Afghanistan, Pakistan, Bangladesh, Iraq, Indonesia, Eastern Europe and Iran now major sending countries. By 2008, Australia ranked as one of three main countries for resettlement of refugees (USCRI, 2009), with the major religious affiliation of refugees in 2006 being Christianity (53\%) and Islam (33\%) (ABS, 2010). As Bouma (2012) points out, the increase in religious diversity produced by the global movement of people and cultures and the proliferation of internal difference within religious communities raises social policy issues in Australia but at present we seem to lack mechanisms for considering and resolving these issues.

Compared with all Australian workers, Muslims exhibit lower employment rates, higher unemployment rates and higher non-participation rates. For example, in 2006 the participation rate for Muslims was only $51.9 \%$ compared to $64.6 \%$ for the total Australian working population (DIAC, 2008). There was a significantly lower employment rate of $44.9 \%$ for Muslims compared to $61.2 \%$ for the total population (ABS, 2006). The unemployment rate of $13.4 \%$ for Muslims was much higher than the general unemployment rate of 5.2\% (ABS, 2006), indicating significant labor market disadvantage. In 2006, only $57 \%$ of Muslim males were employed compared to almost $68 \%$ for the total male working age population (ABS, 2006). The unemployment rate for Muslim males (12.6\%) was more 
than double that of all working men (5.2\%) (ABS, 2006). The work participation gap is even higher for Muslim women (see Nilan, Samarayi, \& Lovat, 2012), a trend that accords with international patterns for Muslim women in non-Muslim countries (see Lovat, 2012). Lower labor-market participation rates and higher unemployment rates for Muslims in Australia may indicate a discouraged worker effect owing to lack of skills and experience, cultural differences in attitudes to work, prejudice in the labor market, disadvantaged socio-economic background, or a combination of factors.

According to the ABS Job Search Experience survey (ABS, 2009), the most common reported difficulties for all jobseekers in 2007 were: poor health or disability; lack of necessary skills or education; unsuitable hours; and insufficient work experience. Other barriers included: distance to jobs or lack of transport; too many applicants for available jobs; no suitable vacancies or no vacancies at all; family responsibilities; and being considered too old. According to a 2005 survey of Australian Job Network (Note 1) staff, significant reported barriers for jobseekers were: poor attitudes and lack of motivation; poor health, mental illness; and disadvantaged circumstances. Disadvantages included: homelessness; perceived insufficient financial gain from employment; lack of suitable vacancies; and problems in meeting administrative demands and reporting to the Job Network (A.C. Neilson, 2005). Another study with Job Network staff in 2007 identified additional barriers: insufficient labor demand; poor soft skills considered essential to successful workforce engagement; transport problems; and dearth of training options (Cook, 2008). Identified employment barriers for Muslim jobseekers included lack of recognition for qualifications, poor English language skills and the "challenge of a host society that has become increasingly hostile to their form of religious expression' (Casimiro, Hancock \& Northcote, 2007: 56). Syed and Ali (2005) noted that ethnic minority women in Australia are subject to both an 'ethnic' and 'gender' penalty in the labor market and are likely to be hampered by cultural expectations that discourage work and limit development of English language proficiency. Moreover, Muslim women can be subject to overt or covert discrimination owing to the visibility of 'difference', especially if wearing a headscarf (see Nilan, Samarayi, \& Lovat, 2012).

Devout followers of the faith might conceive the workplace, as well as the relationship between employee and employer, differently from more secular jobseekers. For many Muslims, there is little separation between the secular and the sacred (Bouma et al., 2003). In principle, paid work should not violate Islamic values, such as fairness and mutual responsibility, or moral guidelines. So for some Muslims, working in places like casinos where Islamic codes of conduct are challenged, goes against their beliefs. Islamic rituals and requirements can also cause difficulties since they may not be understood or even tolerated by employers and non-Muslim colleagues. These include: daily and Friday prayers; ablution; fasting; pilgrimage; Muslim holidays; and shaking hands (McCue, 2008).

Nevertheless, despite all the above-mentioned social, cultural and religious factors that can operate as barriers, Australian census data since 1996 shows that employed Muslim men and women have similar occupational distributions to those of all Australians. And as a group, they are similarly qualified (Akbarzadeh et al., 2009; ABS, 2006), if not better qualified in many cases. For example, $17.5 \%$ of Muslim women aged over 18 had a bachelor's degree or 
higher compared with $18 \%$ of all Australian women over 18 in 2006 (ABS, 2006). Low employment levels therefore cannot be attributed to lack of educational qualifications or skills or, indeed, directly to any of the general barriers listed above, at least in any direct and evidential sense. Imtoual (2010) concludes that prejudice against Muslims in Australia is a form of 'religious racism' (Imtoul, 2010: 56). It seems that anti-Muslim attitudes, negative stereotyping and cultural racism and discrimination, especially since 9/11, constrain opportunities for Muslim jobseekers to engage with the workforce.

\section{Methodology}

The project employed a mixed-methods approach, including econometric modeling of ABS figures, a survey, qualitative interviews and case studies. The approach is described in the project report (DIAC, 2011). This article employs survey and interview data. Survey and interview schedules were designed to elucidate the situations and experiences of Muslim jobseekers and their job-seeking strategies, as well as suggestions for future practice in employment service provision. Both the survey and interview schedules received ethics approval from the University's Human Research Ethics committee and the government funding body.

\subsection{Survey}

104 surveys were completed in late 2009 by Muslim jobseekers aged from 18 to 54 years. They were recruited from employment centers and Muslim and ethnic community groups, centers and associations in Sydney, Newcastle and the Central Coast of New South Wales. The majority lived in western Sydney. The average age was 31 years. $48 \%$ were men and $52 \%$ were women. $75 \%$ were either recent immigrant arrivals or refugees. $53 \%$ had received their residence or citizenship through a humanitarian visa as refugees, $32 \%$ through family membership and only $12 \%$ as skilled immigrants. The next largest group consisted of first generation Muslim jobseekers (14.7\%). A 'snowballing' method was used to recruit respondents. In addition, 14 employment service agency staff completed a modified version of the same survey. Survey data were analysed using PASW (formerly SPSS) software.

\subsection{In-depth Interviews}

Muslim jobseekers self-selected for interview following the survey, yielding 50 interviews. It was difficult to obtain interviews with employment service provider staff, and only seven were completed. Interview data were analysed for emergent themes by seeking trends through a review and categorization process. The selected quotes in this paper are indicative of wider interview trends.

\section{Characteristics of Muslim Jobseekers}

\subsection{Education}

In the 2006 census, $27.5 \%$ of the Muslim population had graduated from high school, or possessed an equivalent qualification, compared to $17.8 \%$ of the total population (ABS, 2006; DIAC, 2007). Survey data reflected this situation: $73.3 \%$ had completed high school and more than $30 \%$ had a post-school qualification. Almost $10 \%$ possessed a bachelor degree and $5 \%$ 
had a postgraduate qualification. This finding was important for the project because it means the Muslim jobseekers did not seem to be disadvantaged in terms of qualifications compared to non-Muslim jobseekers in the same suburbs.

\subsection{Current Work Status}

Survey respondents were either unemployed, looking for full-time work while engaging in part-time or casual paid work, or studying and looking for part-time work. $22.1 \%$ were receiving a government allowance to assist them in finding work, while $18.3 \%$ received the youth allowance. $17.3 \%$ received the Single Parenting Payment and $14.4 \%$ received the Partnered Parenting Payment; 9.6\% reported receiving other government payments; and 19.3\% did not answer the question. This represents a reasonably high level of government financial support which may continue for prolonged periods unless they can find a job.

\subsection{Employment Patterns}

$46.4 \%$ of survey respondents had been seeking work for less than one year while $53.6 \%$ had looked for longer. They experienced a wide range of work types, from factory labor to professional employment. Usual length of time in employment was quite short, from less than one month to seven months. The most common length of time in employment was two months $(33 \%)$ or one month $(28.6 \%)$. Nearly $20 \%$ of respondents had been unemployed for more than a month on two or more occasions. Five respondents experienced unemployment for more than a month on ten occasions and one respondent reported twenty occasions. It is perhaps these figures that indicate most directly the aptness of the United Nations (2010) finding that people of Muslim background in Australia experience discrimination, since this is a highly fragmented work pattern with more firings than hirings, and one that does not fit the qualification profile.

\subsection{Other Characteristics}

Some salient characteristics of Muslim jobseekers were identified from multivariate analysis of survey data. First, no statistically significant difference was found between male and female jobseekers in terms of the length of time they had to spend to find a job (Note 2). However, there was a statistically significant but moderately strong relationship between the jobseekers' visa status and the length of time spent looking for a job (Note 3). This suggests that Muslim jobseekers on humanitarian visas are less likely to find jobs in less than a year, compared with those in other categories. Second, no statistically significant difference was found between those who used an employment agency and those who did not, in terms of the time necessary to find a job. In short, frequency of using an employment agency did not shorten the time length of job searching and unemployment. Third, there are statistically significant correlations (strong to moderate) between the jobseekers' conceptions of religion, ethnicity, age and Muslim identity as main reasons for their failures in finding a job. This indicates that Muslim jobseekers are aware of the intersectionality between discriminatory factors in the labor market, since they do not appear to blame one factor over the others. We turn now to evaluate the influence of their situations. 


\section{Situations of Muslim Jobseekers}

\subsection{Health and Difficult Personal Circumstance}

Most survey respondents 'strongly disagreed' or 'disagreed' that ill health or disability was a barrier for them, although over a quarter indicated age was a barrier. For example, the husband of one interviewee had recently left her. At 49 years of age, she had not worked previously because of child-rearing and so found herself unwelcome in the labor market. She said:

When I arrived to Australia I have 4 kids all of them under age. I wanted to look after them and then find myself. I wish I would have worked when I was young but I at this age 49 years old who would give you a job especially if you are a Muslim? (female, 49 years, Kurdish-Iraqi refugee).

This interviewee was disadvantaged because of her age, gender, family situation and lack of experience. This was a common situation for older Muslim jobseekers.

\subsection{Gender and/or Family Issues}

Caring responsibilities were a significant issue for women. Half of female survey respondents claimed family responsibilities restricted their availability for work and the jobs they could get, for example:

The job I am looking for it has to be part time and casual between school hours 10-12 so Centrelink gave me some information. I have kids so it would be better for me to work in school hours. My youngest child is under 12 (female, 38 years, Iranian refugee).

Family responsibilities were also perceived as a barrier to employment for a quarter of male respondents. This finding reflects strong familial bonds within the Muslim population and perhaps sometimes a lack of extended family support in Australia, particularly for refugees. It may also reflect a lack of quality affordable childcare available in the suburbs where most Muslim jobseekers are living.

\subsection{English Language Issues}

Overall, the majority of subjects perceived their English language proficiency to be adequate. $61 \%$ felt confident 'most of the time' when reading in English and 59\% felt confident when writing English. Women reported slightly higher confidence in speaking, writing and reading than their male counterparts. Conversational English presented the greatest difficulty with $32.3 \%$ of respondents reporting some difficulty in following conversations. Almost $32.7 \%$ reported avoiding speaking English unless necessary and $47.9 \%$ of respondents expressed awareness of their accent. One jobseeker was a fluent English speaker born in Australia, but well aware of the difficulties faced by newcomers in her community:

So many Muslims, their English is very poor and they need help with that first and then they might be ready to take on a job (female, 26 years, Lebanese second-generation). 


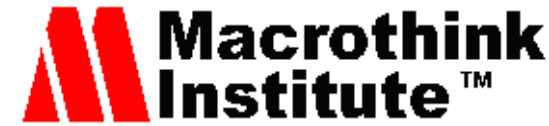

Certainly lack of English really counts against some Muslim jobseekers, for example:

I think the first problem is the language. As if you can't speak English no point of looking for work. Even if you study - if the English is not your first language that would be hard to or to let people understand. I have tried to look for a job and applied but no much respond from them (female, 30 years, Pakistani on temporary visa).

Lack of English signifies a particularly intractable obstacle for Muslim jobseekers that are recent arrivals on humanitarian or family visas (see multivariate analysis findings above). The relative linguistic insularity of ethnic enclaves in western Sydney means they are unlikely to learn English quickly without targeted assistance. One Muslim jobseeker said happily:

'I am living among my community and all of them speaking Arabic. Thank God' (male, 40 years, Lebanese refugee).

His situation is unusual. English was not such a problem because he paints houses on contract with fellow Arabic-speakers. However, this is somewhat unusual. Most of the Muslim jobseekers interviewed were seeking jobs in workplaces where they were expected to communicate in English with co-workers and managers from many different ethnic backgrounds. For recent arrivals this was a significant barrier.

\subsection{Confidence}

Only $57.4 \%$ of survey respondents reported confidence in job interviews even though three-quarters of them agreed their education level and skills were adequate for finding employment. Furthermore, only 53.3\% felt that their CV (portfolio) was satisfactory, indicating some lack of confidence in the effectiveness of this document. Many interviewees mentioned the importance of the CV. For example, when asked about the most valuable thing she had learned from the employment service provider, one woman said:

The CV, how to lay out a CV ... I think the cover letter was the most important thing ... One ... you have to know what the organization's objective is and explain in your cover letter how important it is to you that you share the same goals. And the second one is give performance indicators ... which was rather than saying, 'I am always punctual' on your cover letter you say something like, 'throughout the two years that I was working with so-and-so I only turned up late once and I never called in sick' (female, 23, Kurdish-Iraqi refugee).

Lack of confidence may come from uncertainty about employer expectations, repeated disappointments or unfamiliarity with the genre conventions of a curriculum vitae or portfolio.

\subsection{Preparedness (or Otherwise) to Accept Certain Job}

Labor market conditions were identified as a significant barrier to employment. $48.4 \%$ of respondents agreed or strongly agreed that no suitable jobs were available, while $42.6 \%$ did not have their own transport and believed this was a barrier. Despite this, the same percentage was prepared to commute long distances for work. Just under half were even prepared to relocate 
for work. This was particularly so for men, with female respondents disinclined to relocate. Survey respondents were evenly divided on flexibility in the type of job they would take. All the Muslim jobseekers interviewed said they were ready to work. However, only three said they would accept any job available. Most said that they would not work with alcohol or pork, for example:

Int: Are there particular kinds of work tasks or activities you would not take on as a Muslim?

Participant: Bars, clubs, alcohol places, working in a shop with pork (male, aged in his 20s, Turkish immigrant).

Effectively, this means that for most Muslim jobseekers interviewed, employment opportunities in a high demand labor market sector - hospitality, food and entertainment services - would not be taken up. Restaurants, sandwich shops and catering firms require handling of pork and ham. Restaurants and service/sporting clubs require alcohol to be handled. Bars and clubs may also require contact with adult entertainment. However, it is important not to over-interpret this finding, since many non-Muslim ethnic jobseekers might wish to avoid some of these workplaces, and many Anglo-Australian jobseekers might also be less than enthusiastic.

In examining the situations of Muslim jobseekers glimpsed in survey and interview data, we conclude that while age and English language issues do constitute barriers for some, these are not barriers that apply just to Muslim jobseekers in Australia, but to much wider constituencies of jobseekers that present a disadvantage to labor market engagement. The matter of confidence is also likely to be a challenge for other ethnic jobseekers, and perhaps some less educated jobseekers per se. Furthermore, many female jobseekers are constrained by gender traditions and caring duties to a limited range of employment possibilities, so this barrier is not one experienced just by Muslim jobseekers. Finally, even though Muslim jobseekers are probably likely to be even more disinclined than all jobseekers to take up a job in venues serving alcohol, offering gambling or providing adult entertainment, they are certainly not alone in this disinclination. It would seem that so far, only the possibly infrequent barrier of refusal to work with pork distinguishes Muslim jobseekers per se from other jobseekers. This is insufficient to explain the employment gap for Muslims. In seeking an answer to the question of why Muslim jobseekers in Australia appear to suffer a marked labor market disadvantage, we turn now to consider their experiences of prejudice.

\section{Experiences of Prejudice}

\subsection{Appearance and Accent Issues}

Accent was not a source of anxiety for either sex. However, two-thirds of survey respondents felt that their appearance was a barrier to gaining employment, especially for women. Female interviewees who wore a head scarf (hijab) identified their appearance as the primary obstacle. For example, one participant was educated in English, so language was not a problem, but her appearance seemed to put up an instant barrier for the prospective employer: 
Not my accent but my appearance. So many times when I get a job over the phone and they ask me for interview. I could see the reaction when they see me wearing this scarf. They slam the door in my face (female, aged in her 30s, Malaysian migrant).

The head scarf certainly implied Islamic extremism for some employers:

Al Hijab is the main problem as employers are afraid of this appearance as it could affect the business or they would think because I am covered I could be fundamental or extremist, especially with this bad reputation of Muslims at the moment (female, 25 years, Kurdish-Iraqi refugee).

The hijab enables instant identification as Muslim, and as the interviewee above points out, in Australia it connotes other negative symbolic potential.

\subsection{Ethnic Prejudice and Racism Issues}

$47.8 \%$ felt their ethnic background was not a reason for their lack of success, although 37\% thought it was. One interviewee summed it up precisely as a cumulative stigma:

I think first of all, they - most of them - they check our background. And the second is checking our name and then the third one they looking for the qualification. And the main thing is if you have background like me from Afghanistan, when you are a Muslim, that is it (male, aged in his 40s, Afghani refugee).

One employment service provider reported that sometimes employers prefer people from their own cultural background:

We have experienced situations where employers have requested jobseekers of a particular ethnic background. It might be their own. In [this suburb], for example, we have a lot of Turkish employers who have requested Turkish speakers. English is important too but more about the Turkish ethnicity (female, 32 years, Greek/Egyptian).

While this might be an advantage for Turkish jobseekers, it would be a major obstacle for jobseekers from other ethnic backgrounds. Elsewhere, there was an implication that, if an employer asked about a Muslim jobseeker's ethnicity, it made the applicant feel 'different':

Int: Do you discuss your ethnicity in job interviews?

Participant: Only if they ask.

Int: What kinds of assumptions do you think employers might make about you?

Participant: Mmm, I think they will assume he is - he is a stranger, he is just a stranger (male, aged in his 40s, Kurdish-Iraqi refugee).

Perhaps this participant's suspicions are well-founded. Booth, Leigh and Varganova (2009) conducted an investigation where they submitted job applications in Australia using both Middle Eastern and Western names. They found those with Anglo-Saxon names were more 
likely to be contacted for an interview. It was estimated someone from the Middle East would need to submit $64 \%$ more applications to obtain the same number of interviews. The research also established that a high quality CV increased the call back rate for Anglo-Saxon names by 14 percentage points but Middle Eastern-named applicants 'gain no apparent benefit from having a high-quality CV' (Booth, Leigh \& Varganova, 2009: 13). This may impact upon the confidence of Muslim jobseekers.

\subsection{Problems Arising from Being Muslim}

Almost half of survey respondents suspected they were unsuccessful in their job search directly because of being Muslim. Many interviewees cited examples of outright prejudice against them as Muslims, apparently based on the 'terrorist' assumption, for example:

They dislike Muslims ... They can't trust us because of the news on TV after Sept. 11 , everything is changed (female, aged in her 30s, Palestinian refugee).

Recollections of intolerance were frequent, for example:

They will ask me are you going to bomb the place. This is a very common question. They think all Muslim are terrorists (male, 26 years, Arab-Iraqi refugee).

The fear of violence by Muslims towards non-Muslims in Australia was often referred to:

'they think all Muslims are bad and they could hurt people' (male, aged in his 30s, Sudanese refugee).

Others mentioned the arguably milder perception in the Australian community that Muslims are 'fussy' and 'complicated', for example:

Participant: When I go to look for a job they would look at your scarf and they judge you because of that. I would suffer quietly.

Int: What kinds of assumptions do you think employers might make about you?

Participant: They probably think I am complicated because I am Muslim so they wouldn't give me a chance (male, 41 years, Kurdish-Iraqi refugee).

This idea of being 'complicated' was mentioned several times. For example, one woman who had taken off the hijab said:

'that's why I don't mention my religion so they don't think I am complicated' (female, 41 years, Arab-Iraqi refugee).

The term 'complicated' presumably refers to perceptions that Muslim jobseekers might need to pray during the day, that they have dietary restrictions, that they fast for a month every year, and have other kinds of distinctive behavioural characteristics and cultural norms that might make others feel uncomfortable. Another participant recounted abuse surrounding his choice to pray at work:

I was working in the factory and people over there they abuse me for like you Muslim and like we have five minutes time for that we have to go for prayer and 
they. The boss push us and scream. I said to him, 'look if we go for ten minutes break for prayer what about those people who for one hour, half hour, ten minutes, fifteen minutes go for coffee or cigarette? Why not tell this one?' Because we are Muslim we are not allowed to go for prayer. I said it must be equal. If these people go for smoking, I do not go for smoking I go for prayer. That takes only five minutes of the time (male, aged in his 40s, Afghani refugee).

Some interviewees said they thought the Australian media was responsible for the poor image of Muslims that impeded their success in searching for jobs:

Every day they abuse. If someone does any wrong thing they use Muslim name and make all the Muslim name bad. We can see so many times in the newspaper like that, it happens in Australia specially (male, aged in his 40s, Afghani refugee).

Many concurred with this claim about the Australian media, for example:

They think if a Muslim made a mistake that means all Muslims are bad and criminals. Our reputations are very bad at the moment because of the news and media (male, 29 years, Saudi Arabian temporary migrant).

One female interviewee had taken off her hijab to reduce anti-Muslim prejudice:

I could see people staring at me because of my different look. I used to wear a head cover but now I have to take it off so people could stop treating me in a different way (female, 34 years, Arab-Iraqi refugee).

She was determined to get a job because she had children to support. All these examples show the strength of conviction among interviewees that, based on their experiences, being perceived as Muslim was the major barrier to employment. We turn now to consider the engagement of Muslim jobseekers with employment service providers.

\section{Jobseekers' Experiences with Employment Service Providers}

\subsection{Attendance}

Of the 104 jobseekers surveyed, only 34 were currently using an employment service provider even though all were looking for work. Of these 34 , most attended fortnightly (31\%) or weekly (17.2\%). Some thought the agencies provided a useful service:

The advantage with them is that there is somebody behind you. Like somebody give you guide. This is important particularly if you are new in the country' (male, 40s, Kurdish-Iraqi refugee).

However, $27.6 \%$ reported not attending very often:

I will rather look for on my own because you can't really rely on other people like if they have a lot of other people to look for jobs you have to wait a long time. If you do it yourself you find it easier and quicker (female, 22, Lebanese $2^{\text {nd }}$ generation).

This implies that employment service providers might be used more often by recent arrivals. Asked to detail the assistance they had received in the past three months, $45.5 \%$ of respondents 
discussed skills and experience with their employment service provider, for example:

They improved my resume, they wrote the application for me (male, 40s, Kurdish-Iraqi refugee).

$40 \%$ of respondents were assisted with internet searches, the majority women.

\subsection{Training}

One-third had been assisted for training courses:

They can give you training if you need some sort of training. They can recommend you for training and you can get the money from Centrelink' (male, 30s, Bangladeshi migrant).

One-third of respondents had undertaken computer training. Not quite one-third of respondents had been assisted with numeracy or literacy classes and a similar number had been assisted to undertake English language training. Over half had been assisted to take a technical college course. This is by far the most significant training facilitated by employment agencies. $18.2 \%$ of respondents had had voluntary work or a work trial with an employer organised for them. Nearly $40 \%$ of respondents thought the training courses had been relevant and useful but $53.8 \%$ of male respondents did not find them so.

\subsection{Job Vacancies}

Asked if their employment agency had contacted them about job vacancies in the past six months, only $35.3 \%$ of survey respondents had been contacted. When asked if they had gained employment through their agency in the past six months, $82.4 \%$ said they had not. Some of the interviewees felt strongly about this:

Actually looking for a job is very hard. Agencies are lying to you. They say yes, look for job, look for job but when you tell them I couldn't find a job, no one answering you, no one giving you a job. If you have a CV or any ability, they don't care. The last job I got, it was through a friend - working in a factory (male, 26, Arab-Iraqi refugee).

There were many such comments in the interviews. One man said frankly:

I have help from my friends more than any other organisation or service' (male, 27, Iranian second generation).

In short, Muslim jobseekers rely on their social capital bonds in the ethnic communities where they live for many forms of support, and finding out about jobs is clearly one of these forms of support. Their relationship with employment service providers is intermittent and sometimes reluctant.

In summary, only $40 \%$ of respondents were satisfied with the services offered by employment agencies although two-thirds of female respondents were satisfied with services. Yet only two-fifths of respondents thought employment agency staff showed a good understanding of them as Muslim jobseekers. Once again, the majority were women. Men, either disagreed $(42.9 \%)$ with this statement or felt ambivalent (42.9\%). In summary, it seems that Muslim men, rather than women, were dissatisfied with employment service provision. 


\section{Views of Service Providers}

\subsection{Supportive}

Most of the employment service provider staff we interviewed supported the views of Muslim jobseekers about the employment barriers they faced. For example, a western Sydney worker said:

Most of our clients are Muslim in this area and there's a high rate for unemployed people' (female, 34 years, Spanish speaking, Asian background).

Another agreed:

I think in the area they would face some barriers because of the perceptions, the society's perceptions. How they think about what's been going on. Yeah, I think they do have difficulties compared to other people' (female, 27 years, Italian).

Our finding that Muslim jobseekers seemed to lack confidence was supported:

Getting a job, I would say a larger proportion of Muslim jobseekers would lack confidence' (female, 32 years, Greek/Egyptian).

As a corollary to this point, one of the employment service provider staff running a program specifically for Muslim jobseekers observed that:

We have a very high employment rate ... out of our Muslim employment program. And it's mostly about confidence' (female, 30s, Lebanese (Australian raised)).

The problem of negative employer perceptions of Muslim workers was clearly explained by one of the workers:

I think some employers may not understand, may think that Muslim jobseekers, if they employed a Muslim jobseeker that they would request to leave the work place frequently to pray. So maybe a perception around prayers not sure what it means but think that is going to impact on the day's job ... they may think if they were to employ a Muslim person from the Middle East or even somewhere like Malaysia that they might have connections to terrorism, crime, social problems (female, 32 years, Greek/Egyptian).

Further to experiences of discrimination, another employment service worker in the program for Muslim jobseekers remarked that:

There can be problems with a perception of discrimination especially with women wearing the hijab ... they are knocking themselves out of the process of getting a job because of fear of discrimination (male, 30s, Anglo-Australian).

The same specialised employment service worker identified problems with some standard employment service providers:

We do a lot of advocacy work around refugees in particular and even the Muslim employment program ... a large part of what we do is provide information sessions to service providers, whether they be RPOs [recruitment process outsourcing], other employment providers etc or businesses and it is just amazing the ignorance of the 
providers out there. It's almost as if it, I don't know, it really blows me away. I don't understand how people can live in this world and be so ignorant of other cultures but it's a huge, huge issue (male, 30s, Anglo-Australian).

As this service provider indicates, the problem of lack of awareness on the part of employment service providers can add to the challenges for Muslim jobseekers.

\subsection{Unsupportive}

A frequently-found view was that Muslim jobseekers are no different from others seeking work:

They [Muslim jobseekers] are just like every other jobseeker that we have coming into this office. There is no difference. So everybody is the same. I can't see any being different to another person' (female, 62 years, Anglo-Celtic).

This may perhaps represent a misunderstanding about the nature of equity in service. More strongly negative views were also expressed at times:

It is the attitudes and the English language to be very honest with you. ... Muslim jobseekers are difficult to place in a position or place because they're not motivated for work. It seems to be cultural thing. I am not sure if it is the ethnic background as well or any other reason. ... With jobs they are very reluctant. They would go to local only. $\mathrm{Um}$, and this is my assumption, sometimes there are some medical problems which are non-existent. I don't know from where they would bring the medical exemption. I have a man just recently he told me 'I can't work because my wife is pregnant'. It is like something fragile when his wife is pregnant. When I said this is not enough reason he was really irate and yelling. Very difficult. So many issues and some of them are very ridiculous (female, 48 years, Irish/Scottish).

It would seem that this service provider has become frustrated in dealing with Muslim jobseekers and has developed a rather negative attitude. This would not provide a positive experience for Muslim jobseekers. She added that:

90\% of Muslim Jobseekers are not very keen to go to English classes. If we want to send them to do a course they're very inflexible and reluctant. They wouldn't like to travel outside [the suburb], particularly women. If we send them to [next surburb] to do a course they would say it is too far even if it is two stops in the train (female, 48 years, Irish/Scottish).

Finally, there was evidence in the interviews with employment service providers that some regard Muslim jobseekers as getting a free ride on government bene fits with no obligation to work:

I am not seeing any enthusiasm [for jobs]. Unfortunately for the young ones they see at home quite often and think it is right to take money from the government and they don't have to return that (female, 34 years, Spanish speaking, Asian background).

Once again, one might assume that the level of service support might be compromised by this 
negative attitude.

\section{Discussion}

The data presented above would seem to bear out the United Nations observation that, in Australia, there are ongoing issues of discrimination and inequity experienced by people from Muslim backgrounds. The history of modern Australia is founded on immigration, so it is troubling to find that Muslim jobseekers are struggling to solidly engage with the labor force. It is also disturbing to find that sometimes employers do not want to employ them and that employment service staff sometimes misunderstand and poorly judge them. In our study, Muslim jobseekers described many work obstacles that beset migrants regardless of religion, such as educational background, ethnicity, English-speaking competence, experience, gender and age. Yet, they also spoke a lot about being Muslim and the problems that this caused for them. As indicated earlier, the realisation that religion may now be a determining factor in employment status echoes earlier sectarian periods in Australian history when religious prejudice in employment practices was notable. Australia now has laws that make this unlawful, but there are many grey areas of practice in recruitment and employment that seem to make such exclusion still possible.

Although there was much evidence in the study that Muslim jobseekers, especially younger people (Nilan, 2012), relied greatly on the internet and word of mouth to find jobs, there is no doubt that employment service providers are very important for many. The jobseekers relied not only on job search support from these offices but on other services and programs that boost their confidence and wellbeing. The best experience for them was to engage with compassionate, culturally sensitive, and individualised approaches and programs. The claim that 'we treat everyone the same' might not comprise optimal wisdom for employment service providers dealing with Muslim jobseekers whose adherence to religious rules needs to be respected. Yet, at the same time, not all Muslim jobseekers are the same, as our data amply demonstrated. The fact of multiple differences within the Muslim community further challenges the suitability of any form of the 'one-size-fits-all' approach by those who assist them to find jobs.

\section{Conclusion}

We have analysed findings from a research project that examined the job readiness of Muslim jobseekers and identified a range of employment challenges that lie behind the high unemployment rates of Muslims in Australia, as noted by the United Nations. In spite of our initial misgivings about conducting research about jobseekers based on the target group's religious faith, 'Muslim Jobseekers' in fact turned out to be an entirely suitable and helpful way of identifying a particular set of problems that pertain to this population. While there were many factors that impacted on the employment wellbeing of this population, rarely did those factors cohere consistently around a theme other than the fact that they were Muslim. This seemed to relate not so much to the religious dimension of the group but to the fact that factors negatively influencing migrant labor market access were exacerbated for Muslims who were looking for jobs. So, while the general effects of having a non-English speaking background, of being an immigrant, a refugee, of coming from a stigmat ised ethnic group, of 
being female, being older, and so on, showed up as barriers to employment wellbeing in the ways one would expect, the effects on the Muslim who fitted any or all of these categories were more profound. It is a worrying sign for Australia, as the land of the 'Fair Go' society, that these forms of anti-Muslim discrimination can be found so easily and so persistently. Of particular concern was the 'revolving-door' of serial episodes of unemployment for a high number of informants. This is a scenario that can be expected to have major negative financial implications and broader social exclusion ramifications for the families of these Muslim jobseekers.

Data from our 2009 project on Muslim jobseekers point not only to some past shortfalls in employment service provision but to perceived negative attitudes of employers and co-workers, who are just as crucial for effective labor force engagement. Changing intolerant and fearful attitudes in such a diverse range of settings and status positions is challenging. Recommendations that flow naturally from this situation include the following: first, a concerted effort is needed at whole-of-government level to address the growing trend towards anti-Muslim prejudice and discrimination that is clearly threatening not only Australia's reputation as a fair society but moreover the very fabric of its security and wellbeing; second, the prime targets for such whole-of-government action should be public institutions like education, the media and government and semi-government agencies such as community services and employment agencies; third, the direct involvement of appropriate Islamic religious authorities is required to ensure any action is built around partnership between all stakeholders; fourth, and most directly, action should be directed towards counselling and supporting Muslim jobseekers to be able to work as flexibly as is the norm within the Australian labor market; finally, we recommend that further and more intensive research of the kind represented in this paper continue to be supported by appropriate agencies to ensure that covert forms of discrimination, such as have been uncovered by our research, are exposed and, in the spirit of equal employment opportunities, eliminated.

\section{References}

ABS (Australian Bureau of Statistics). (2006). 2006 Census of population and housing. Canberra: Australian Bureau of Statistics.

ABS (Australian Bureau of Statistics). (2009). Job search experience, Australia, July 2008, Cat. No. 6222.0. Canberra: Australian Bureau of Statistics.

ABS (Australian Bureau of Statistics). (2010). Perspectives on migrants, June 2010, Cat. No. 3416.0. Retreived from http://www.abs.gov.au/AUSSTATS/abs@.nsf/Lookup/3416.0Main+Features2June+2010

ABS (Australian Bureau of Statistics). (2012). 2011 Census of population and housing. Canberra: Australian Bureau of Statistics.

Adeleke, I., \& Ibiwoye, A. (2011). Network sampling of hard-to-reach population: an application to the substance abuse problem among tertiary education students in Nigeria. International Journal of Asian Social Science, 1, 133-141. 
Akbarzadeh, S., Bouma, G., \& Woodlock, R. (2009). Mapping employment and education among Muslim Australians. Melbourne: Centre for Muslim Minorities \& Islam Policy Studies, Monash University and Department of Immigration and Citizenship.

Booth, A., Leigh, A., \&Varganova, E. (2009). Does racial and ethnic discrimination vary across minority groups? Evidence from three experiments. Canberra: Australian National University.

Bouma, G. (2012). Religious diversity and social policy: an Australian dilemma. The Australian Journal of Social Issues, 47, 281-295.

Bouma, G. Haidar, A., Nyland, C., \& Smith, W. (2003). Work, religious diversity and Islam. Asia Pacific Journal of Human Resources, 41, 51-61.

Byng, M. D. (2008). Complex inequalities: the case of Muslim Americans after 9/11. American Behavioral Scientist, 51, 659-674.

Casimiro, S., Hancock, P., \& Northcote, J. (2007). Isolation and insecurity: resettlement issues among Muslim refugee women in Perth, Western Australia. Australian Journal of Social Is sues, 42, 55-69.

Coates, R. D. (2011). Covert racism: theories, institutions, and experiences. Leiden and Boston: Brill.

Cook, B. (2008). The job network: inno vative, effective, efficient? In G Wrightson (Ed.), The labour underutilisation, skills shortages and social inclusion conference (incorporating the 10th path to full employment conference and the 15th national conference on unemployment). Callaghan N.S.W.: Centre of Full Employment and Equity, The University of Newcastle.

DIAC (Department of Immigration and Citizenship). (2006). Accessible government services for all: 2006 annual report. Canberra: Department of Immigration and Citizenship.

DIAC (Department of Immigration and Citizenship). (2007). Muslims in Australia: based on the 2006 census of population and housing. Canberra: Programme Statistics and Monitoring Section, Department of Immigration and Citizenship.

DIAC (Department of Immigration and Citizenship). (2008). The people of Australia: statistics from the 2006 census. Retrieved from www.immi.gov.au/media/publications/research/_pdf/poa-2008.pdf

DIAC (Department of Immigration and Citizenship). (2011). Australian Muslim jobseekers: labour market experience, job readiness, and the relative effectiveness of employment support services. Canberra: Department of Immigration and Citizenship. Retrieved from http://www.immi.gov.au/media/publications/research/_pdf/muslim-jobseekers.pdf

Imtoual, A. (2010). Racism and resistance: everyday experiences of Muslim women in Australia. In S. Akbarzadeh (Ed.), Challenging identities: Muslim women in Australia (pp. 56-75). Melbourne: Melbourne University Press.

Khattab, N. (2012). 'Winners' and 'losers': the impact of education, ethnicity and gender on 
Muslims in the British labour market. Work, Employment \& Society, 26, 556-573.

Lloyd, K., Suchet-Pearson, S., Wright, S., \& Burarrwanga, L.L. (2010). Stories of crossings and connections from Bawaka, North East Arnhem Land, Australia. Social \& Cultural Geography, 11, 701-717.

Lovat, T. (Ed.). (2012). Women in Islam: reflections on historical and contemporary research. Dordrecht, Netherlands: Springer.

McCue, H. (2008). The civil and social participation of Muslim women in Australian community life. Bundoora, VIC: Edsoc Consulting.

Neilson, A. C. (2005). Job network frontline staff survey. Melbourne: Jobs Australia and Brotherhood of St Laurence.

Nilan, P. (2012). Young, Muslim and looking for work in Australia. Youth Studies Australia, 31, Supplement: national youth sector conference 2011 (selected papers) - Interrupting transmission: youth/change/policy/practice.

Nilan, P., Samarayi, I., \& Lovat, T. (2012). Female Muslim jobseekers in Australia: liminality, obstacles and resilience. International Journal of Asian Social Science, 2, 682-692.

PEW (2011). Muslim-Western tensions persist. PEW Research Centre. Retrieved from http://www.pewglobal.org/files/2011/07/Pew-Global-Attitudes-Muslim-Western-Relations-FI NAL-FOR-PRINT-July-21-2011.pdf.

Poynting, S., \& Mason, V. (2007). 'The resistible rise of Is lamophobia: anti-Muslim racism in the UK and Australia before 11 September 2001. Journal of Sociology, 43, 61-86.

Poynting, S., \& Noble, G (2004). Living with racism: the experience and reporting by Arab and Muslim Australians of discrimination, abuse, and violence since 11 September 2001. Sydney: Human Rights and Equal Opportunity Commission.

Quayle, A., \& Sonn, C. C. (2009). The construction of Muslims as 'Other' in mainstream Australia's print media. The Australian Community Psychologist, 21, 8-23.

Rashid, T. (2007). Configuration of national identity and citizenship in Aus tralia: migration, ethnicity and religious minorities. Alternatives: Turkish Journal of International Relations, 6 , $1-27$.

Salleh-Hoddin, A., \& Pedersen, A. (2012). Experiences of discrimination by Muslim Australians and protective factors for integration. The Australian Community Psychologist, 24, 43-58.

Sanitosis, A. (2004). Embodying ambivalence: Muslim Australians as 'other'. Journal of Australian Studies, 28, 49-53.

Syed, J., \& Ali, F. (2005). Minority ethnic women in the Australian labour market (MPRA Paper No. 8892). Retrieved from http://mpra.ub.unimuenchen.de/8892/

United Nations (UN). (2010). Consideration of reports submitted by states parties under article 


\section{Macrothink}

9 of the convention. Concluding observations of the Committee on the Elimination of Racial Discrimination: Australia. Committee on the Elimination of Racial Discrimination, Seventy-seventh session, Geneva, $2-27$ August 2010. Retrieved from http://www2.ohchr.org/english/bodies/cerd/cerds77.htm

USCRI (US Committee for Refugees and Immigrants). (2009). World refugee survey: tables and graphs, resettlement by country Retrieved from http://www.refugees.org/FTP/WRS09PDFS/Resettlementbycountry.pdf

Wise, A., \& Ali, J. (2008). Muslim-Australians and local governments: grassroots strategies to improve relations between Muslim and non-Muslim-Australians. Sydney: Department of Immigration and Citizenship and Centre for Research on Social Inclusion, Macquarie University.

\section{Notes}

Note 1. Job Network: former name of Job Services Australia, an Australian Government-funded network of organisations, contracted through the Department of Education, Employment and Workplace Relations (DEEWR), to deliver employment support services.

Note 2. Chi Square $=0.73$ and Sign. 0.27 .

Note 3. Eta $=0.335$ with Sign. 0.025 .

\section{Copyright Disclaimer}

Copyright reserved by the author(s).

This article is an open-access article distributed under the terms and conditions of the Creative Commons Attribution license (http://creativecommons.org/licenses/by/3.0/). 